\title{
Ssciendo
}

Ethics \& Bioethics (in Central Europe), 2018, 8 (1-2), 51-61

DOI:10.2478/ebce-2018-0001

\section{Patočka, Charter 77, the state and morality: "May it all be for the benefit of the community!"1}

\author{
L’ubica Učník ${ }^{2}$
}

\begin{abstract}
In this paper, I will argue that Patočka's decision to become a signatory and one of the spokesperson of Charter 77 was both deeply informed, and in fact necessitated, by his whole philosophical understanding. I will suggest that the importance of Patočka's contribution to Charter 77 goes beyond the original aim of the declaration, pointing to the broader significance of the moral and political crisis in a society reduced to the sphere of instrumental rationality. For Patočka, to think about humans and their existence in the world is irreducible to instrumental rationality.
\end{abstract}

Keywords: Patočka, Charter 77, truth, means and ends practical rationality, instrumental rationality, morality

„No society, no matter how well-equipped it may be technologically, can function without a moral foundation, without convictions that do not depend on convenience, circumstances, or expected advantage. Yet the point of morality is to assure not the functioning of a society but the humanity of humans. Humans do not invent morality arbitrarily, to suit their needs, wishes, inclinations, and aspirations. Quite the contrary, it is morality that defines what being human means" (Patočka, 1989/1977, p. 341).

In 1976, the government of the Czechoslovak Socialist Republic ratified, along with other states, the Covenant on Civil and Political Rights, which was proposed by the United Nations. It was "[a]dopted and opened for signature, ratification and accession by General Assembly resolution 2200A (XXI) of 16 December 1966" and it came "into force 23 March 1976, in accordance with Article 49" (United Nations, 2017). An informal civic movement was formed to use this occasion to draw attention to the persecution of citizens in the Czechoslovak Socialist Republic in violation of the Covenant, by releasing Charta 77; which called upon the government to uphold the Covenant's principles. The Czech phenomenologist Jan Patočka was both a signatory of Charta 77 and one of three spokespersons to represent this civic movement.

In this paper, I will argue that we can think about Charta 77 in two different ways. On the one hand, Charta 77 is a particular instance of a political action in a particular political situation; and on the other hand, as Patočka also thought, it is a confrontation with the deeper meaning of the crisis of society, transcending its particularity. I will take up the side of its universal aspiration and significance, which is not tied to its particular historical milieu. Hence, I will not consider its historical importance, but its universal implication. ${ }^{3}$ To put it differently, the particular instance of Charta 77's formulation is concerned with the Czechoslovak socialist government of the time and its non-compliance with the treaty on human rights. Patočka of course concurs with this aim, but he extends his concerns to assert that the aim of Charta 77 is to achieve "subordination of politics to the law, and not the law to

\footnotetext{
${ }^{1}$ The title for this paper is taken from a recently published book containing documents on Jan Patočka from the Archives of the Czechoslovak State Security Service (Státní bezpečnost) (Blažek, 2017).

${ }^{2}$ Murdoch University (Australia); email: L.Ucnik@murdoch.edu.au

${ }^{3}$ For a discussion on Charta 77, see, for example, Kraus, Blum, Matuštík, Bolton, Skilling, Jarvinen (Kraus, 2007; Blum, 2005; Matuštík, 2007; Bolton, 2012; Skilling, 1981; Jarvinen, 2009).
} 
politics, as is currently the case" (Blažek, 2017b, 4 March 1977, D 57, p. 215). In other words, Patočka's position is not limited to a particular instance, relating to and defining the Czechoslovak government's abuse of the legal system; he also invokes a general rule regarding an important linkage between any and every government in relation to the law of the State. There is a crucial difference to account for: either the State can define and change the law arbitrarily, based on the ruling Party's preferences or lobbyists' influence on the formulation of policies, or define the parameters within which state policy can be formulated.

In what follows, I will use Patočka's philosophical reflections on the problematic confusion between instrumental politics and morality that Charta 77 addressed, and will supplement them with his other writings, to consider the present crisis in the light of the history of ideas.

Ivan Chvatík suggests that Patočka's lifelong struggle is a reflection on the crisis of European humanity (Placák, 2017a, p. iv): Patočka follows, extends and changes Edmund Husserl's thinking (see Husserl, 1970). Chvatík also notes that, at the end of his life, Patočka's reflections were about 'post-Europe', which we now usually refer to in terms of 'globalisation' (Placák, 2017a, p. iv). There is no doubt that science and technology - two intertwined successors of European philosophy - have conquered the world. The problem is that these two inheritors have appropriated only a part of their inheritance, forgetting that the victory of technical solutions was originally based on a European spiritual foundation, which has become overlooked and eclipsed in the contemporary world. The result is a one-sided techno-scientific rationality that should concern us all (see also Patočka, 2002a, p. 9).

In this paper, then, reflecting on today's society and its framing-in by the culture of cybernetics, algorithms and social media - along with their ostensible propagation of 'posttruth' derived from alternative or false 'facts' - I will suggest that the problem of technoscientific reasoning, stripped of its inner connection with the original spiritual foundation, is also an issue of truth, as well as an issue of morality; leading to the issue of human existence. According to Patočka, "it is morality that defines what being human means", not the other way around (Patočka, 1989/1977, p. 341).

\section{Charta 77}

The year 2017 marks the 40th anniversary of the publication of Charta 77, which led to Jan Patočka's death (1907-1977), following interrogation by the State Police. According to Michael Kraus, Charta 77 redefined "[W]estern notions of civil society" (Kraus, 2007, p. 136), whereby, in the words of Barbara Falk, it "drew a line between politics and morality that effectively changes our perspective on politics" (Kraus, 2007, p. 136). From this position, Charta 77 showed a discordance between politics and morality - politics, which has been the space of violence; and morality, which has become superfluous to 'real' politics, thereby ignored and relegated to 'outside' of the instrumental sphere of government.

Charta 77 was released in January 1977. In the accompanying essay, "The Obligation to Resist Injustice", Patočka recalls the crisis at the heart of techno-scientific rationality, when he writes, "If human development is to match the possibilities of technical, instrumental reason, if the progress of knowledge is to be possible, humankind...[needs] something that in its very essence is not technological, something that is not merely instrumental: we need a morality that is not merely tactical and situational but absolute" (Patočka, 1989/1977, p. 340).

There are two ways to approach Charta 77 and Patočka's essay. Either these texts can be seen as assertions of the so-called metaphysical language of absolute morality and human rights; or it might be argued that Charta 77 did not describe the pathological symptoms of 'really existing socialism' by revoking the empty metaphysics of human rights and morality, but rather, productively inserted into the midst of human affairs - in the stifled atmosphere of this 'really existing socialism' - different ways of thinking and understanding the world in the 
late 1970s. Patočka's other texts can be seen in this light too. Thus, in today's world, to reflect on Patočka's claims regarding the importance of morality for human society is to recognise his continuous attempt to open and take up the possibility of creating a different understanding of the present. Such an understanding can help us to reconfigure techno-scientific reasoning in a world where the absolute, divine ground is no more, leaving human moral conduct supposedly without firm ground. To reflect on Patočka's understanding of 'morality' is to take up the history of ideas and, thereby, also to reflect on his writing as an active ingredient in forming new ways of thinking and living.

\section{The crisis of the state}

Patočka was one of the three spokespersons of Charta 77 (with Jiří Hájek and Václav Havel). As Cerwyn Moore reminds us: "Patočka's decision to take an active role as a spokesperson in Charta 77 placed him in a dangerous position at the forefront of the Czechoslovak dissident movement" (Moore, 2010, p. 80). The recent publication of documents on Patočka amassed by the State Police reveals their level of knowledge related to his health. His personal doctor, Vlastimil Ježek, an agent of the State Police from 1974 under the cover name 'Kliment', (Blažek, 2017a, p. 20; Placák, 2017b, p. ii) exposed the history of Patočka's ailments, declaring that he was at risk of heart attack, stroke, and so on, "which can happen anytime" (Kliment, 12 Feb 1977, D 48, p. 188). Hence, the incompatibility between State actions and morality was starkly brought to the fore by Patočka's death. Patočka's exhaustion, caused by the State Police's investigation into his interview with the Dutch foreign minister, Max van der Stoel, on 1 March 1977 exacerbated his chronic bronchitis, leading to his death. As the released documents establish, the State Police was aware of Patočka's condition. The final report simply confirmed the expected end of their actions: "Medical report - Conclusion: Advanced chronic ischemic heart disease. Chronic bronchitis. Stroke" (doc. MUDr. Albert Válek, Dr.Sc, 14 March 1977, D 67, p. 236). ${ }^{4}$

Is it possible to trace a link between the actions of the State and Patočka's understanding of moral action? What was Patočka's position on morality, which he expounded in the texts accompanying Charta 77? Were his philosophical convictions related to his action as one of the signatories of Charta 77 ?

I will argue that Patočka's decision to become a signatory and one of the spokespersons of Charta 77 was deeply informed by his whole philosophical understanding; ${ }^{5}$ a decision that led to repeated investigations, exhaustion and eventually his death in hospital a few days after a day-long police interrogation. ${ }^{6}$ Ludwig Landgrebe offers a description of both Patočka's death and his involvement in the political at the end of his life, which I propose here to follow and substantiate, "Patočka has chosen a fate, for which Socrates was the great model. In the beginning of philosophy, Parmenides spoke of the signs which stand on the difficult path to truth, Patočka's death has placed one such sign" (Landgrebe, 1977, p. 290).

Patočka's philosophy and his reflections on morality show their continuing relevance today. He clearly objects to the designation of the signatories of Charta 77 as dissidents: during his interrogation on 12 January 1977, he notes that they are not followers of Prague

\footnotetext{
${ }^{4}$ The more detailed record of Patočka's death is: "Medical report - Conclusion: Acute ischemic heart disease. Atrial fibrillation. Chron. bronchitis. Susp. embolism a. cerebi media. Hemiplegia. Aphasia" (doc. MUDr. Albert Válek, Dr.Sc, 14 March 1977, D 68, p. 238).

${ }^{5}$ For a similar claim, see also Petr Blažek and Ivan Chvatík (Placák, 2017b, pp. ii-iii; Placák, 2017a, p. iv).

${ }^{6}$ In 1976, Patočka signed a letter of protest against the prosecution of members of the underground group, The Plastic People of the Universe (Placák, 2017a, p. v). The prosecution of the group and opposition to it led to the formulation and subsequent publication of Charta 77. Patočka famously said that he could not listen to their music, but he would do whatever it took to defend their right to critique the government (see Placák, 2017b, p. ii; Patočka, 2006/1976; draft of the translation: Patočka, 2017).
} 
1968 politics, and are not dissidents. ${ }^{7}$ They are a part of politics, and not outside of it: Charta 77 does not aim to interfere in the politics of the Czechoslovak government because its goal is "to participate in public critique" (12 Jan 1977, D 139, p. 453). In other words, the publication of Charta 77 aimed at opening up the space of debate that was closed in socialist Czechoslovakia. Yet, Patočka's critique is not simply a critique of socialism per se, although it is also that. Patočka recognises a larger context: that of this particular crisis as one case, among many others, of the overall crisis in our society; which is the outcome of the problematic nature of morality and politics in a world where God is dead, as Nietzsche announced (Nietzsche, 1974/1882, §125, pp. 181-182). To put it differently, Patočka attempts to think through the loss of transcendence that had previously grounded our finite human morality, and his starting point on this road is Socrates, "a discoverer of human historicity" (Patočka, 2007/1948, pp. 23-24).

\section{Politics and the state}

To reflect on Charta 77 is to realise that the incompatibility between the actions of government, law and morality is not only a defining feature of the (now non-existent) 'real socialism', but is also a problem for the very much existing 'real liberalism'.

In the domain of politics as it is 'practised' today in the sphere of instrumental rationality, we have forgotten that 'planned' ends are not the same as 'human ends'. Discussing Patočka's Heretical Essays, Paul Ricœur explains that "politics is always of another order than economic management...[and] the end of politics is nothing other than life for the sake of freedom, not life for the sake of survival or even for well being" (Ricœur, 1996, p. viii). An important note should be inserted here. Ricœur's formulation of politics harks back to Patočka's and Hannah Arendt's texts and their conception of the polis (Patočka, 1996; Arendt, 1998/1958). On this interpretation, politics is the "sharing of words and deeds", as Arendt formulates it (Arendt, 1998/1958, p. 197). It is a safe space for debate, where citizens can present their different points of view and together consider their present situation. It is a space for rational, although agonistic, decision-making, as we would say today. In contrast, current politics is concerned with the management of the State relying on numerous experts and not on debate with citizens, ${ }^{8}$ who have now been designated as clients of the State. Citizens - which Charta 77 aimed to bring back into debate with the State - seem to have disapeared altogether. ${ }^{9}$ Politics is reduced to instrumental economic considerations, supported by changeable policies, to claim as its 'legal' domain only the fiscal management of the State. These policies are designed to be 'applicable' to the material domain, the domain of things.

\section{Means and ends}

To think about the difference between governing things and governing people, it is important to pay attention to the instrumental rationality that is a defining feature of our present day. Instrumental rationality is originally derived from the sphere of making. It is based "on the fact of purposiveness, on the model of techne, on the relationship between means and ends with which ordinary, routinely practical human life operates" (Patočka, 1989/1953, p. 180). Aristotle points out the difference between the sphere of human action and the sphere of things in terms of the difference between praxis and poiessis; the latter being the sphere of techne, concerned with know-how regarding things, with production. Arendt explains the

\footnotetext{
${ }^{7}$ The understanding of the other Charta 77 signatories themselves as dissidents, or not, is not addressed here.

${ }^{8}$ For a similar position, see Rancière, 1999.

${ }^{9}$ It could also be pointed out that economic inequality, which is becoming very visible these days, or the movement "Black Lives Matter" could lead to the renewal of debate concerning the human rights of all citizens in the State. Indeed, it could lead to questions relating to the designation of citizens as clients of the State and what the implications are for this innocuous substitution. This angle is outside of the present argument.
} 
danger of conflating these two spheres by applying the model of production to human actions. Once human action is thought of on the model of 'production' - in other words, as something that can be achieved by 'planning' or producing - then "by applying the absolute - justice, for example, or the 'ideal' in general (as in Nietzsche) - to an end, one...makes unjust, bestial actions possible" (Arendt, 2005, p. 3, italics removed). In other words, if we posit that we can concretely achieve ideal justice in the world through proposing policies, we forget that this producible 'justice' can only be a particular instance of justice, which by this very gesture becomes an achievable end. We lose any historical consideration of what 'justice' means, as Socrates inquired a long time ago. The 'means' leading to this posited end become prioritised over the end, which we have, after all, already decided that we can produce. Arendt recognises this danger when she writes, "the 'ideal', justice itself, no longer exists as a yardstick, but has become an achievable, producible end within the world" (Arendt, 2005, p. 3 , italics removed).

In the modern age, we have privileged and extended the side of practical rationality, whereby the production process does not end with the produced thing but, rather, the process itself becomes primary. The end is never really an end, but becomes a means for some other end. Hence, the 'means' are prioritised over 'ends'. Any means available are 'good' if we decide that the end is achievable. Where human actions are concerned, exporting democracy to Iraq is a recent example of the impossibility of planning an end as if we were dealing with the production of a vase.

In the production process, in the domain of things, when we decide to produce a vase, the process ends with the vase itself. The vase closes the process and the means are only an instrument to achieve this concrete end: they are a part of the process. On the other hand, hou heneka, 'for the sake of which' we do something - which is relevant to 'human ends', human existence, as Patočka says - is not of the same order. It is not possible to conduct human action in the same manner. There is no clear particular end of a 'process'. There are many possibilities open to us, and by choosing some, we close others. For Patočka, "life is a life in possibilities characterized by a relation to our own being; we project that for the sake of which we are, that for the sake of is the possibility of our life" (Patočka, 1998, p. 177, italics in original).

Means, in the sphere of human experience, are "directed at life, beautiful and good, and worthy of being sought for [their] own sake" (Taminiaux, 1997, p. 38), because we are free to take up the possibilities that we are - or ignore them - to fight for the good that cannot be a part of the world. There is no clear, achievable end. Good is something we strive towards, but cannot reach. It might guide us in our lives through our choosing from present possibilities, but those possibilities will lead to other possibilities. There is no end that we can predict. As Aristotle would have it, praxis is opposed to poiessis; "praxis[,] being oriented toward livingwell[,] is free because its desire is liberated from sheer necessities and usefulness" (Taminiaux, 1997, p. 37). Taminiaux explains that if we apply 'means' from the domain of things to the domain of humans, "life would remain imprisoned within an infinite circle of means and ends, we would merely choose something for the sake of something else" (Taminiaux, 1997, p. 37). In that case, the space of freedom would be reduced to determined 'options', however boundless, that we could select from, believing that they lead to a chosen end. Nothing new could happen in "this endless process of usefulness", which "would render every desire futile and vain” (Taminiaux, 1997, p. 37).

\section{The discordance between politics and morality}

The idea of human rights is nothing other than conviction that even states, even society as a whole, are subject to the sovereignty of moral sentiment: that they recognize something unconditional that is higher than they are, something that is binding even on them, sacred, 
inviolable, and that in their power to establish and maintain a rule of law they seek to express this recognition (Patočka, 1989/1977, p. 341).

For Patočka, to think about humans and their existence in the world is irreducible to instrumental rationality. In the case of the State and its 'management by experts', human ends become problematic, because they are unpredictable. This is the point he makes when speaking of the law and the State. It is in the order of Socrates' question to Euthyphro: "Is the pious being loved by the gods because it is pious, or is it pious because it is being loved by the gods?" (10a) The issue is, as Plato shows in his dialogues, unquestioned tradition. Euthyphro simply does not know what justice is, what pious means or what good is - which he claims to defend. His parroting of the old, unquestioned precepts simply exposes his ignorance of his own actions, which he claims to understand.

Patočka makes clear in Plato and Europe that the "community is traditionally administered by certain rules. In a community that is administered as it should be justice rules. But this justice should not be apparent justice, meaning justice for the exterior, justice for the consequences of justice; rather, it should be justice for the sake of justice, because it is understood that justice is something good and right" (Patočka, 2002a, p. 104). Patočka's point is again general, concerning means and ends. If we accept that "right and justice [are] a matter of utility, an external utility, as a matter that can be put to a specific test" (Patočka, 2002a, p. 104), then we have already accepted that this is something we can produce, plan and achieve by means of experts. Justice as the idea guiding our understanding becomes unthinkable, since it is not something in the world. In our everyday world, we experience numerous cases of just or unjust actions, but the idea of justice is of a different order. We cannot experience it but we can think it and it can guide our conduct. The idea is not something positive, empirically testable. If we forget this side of our human experience, then justice - taken as something we can produce, measure and apply - becomes a matter of convenience, relative to the changeable wishes of the rulers of the day. There is nothing left to decide what is right and just: the yardstick that Arendt speaks about has disappeared. Yet, as Patočka notes, justice and arête (excellence/virtue) are what makes humans who they are: "what makes man in the good sense of the word" (Patočka, 2002a, p. 105). He expresses a similar sentiment in the supplementary text to Charta 77, which I have already cited: "it is morality that defines what being human means" (Patočka, 1989/1977, p. 341); it is an idea that we can strive towards and think about. However, the idea is not something that we can produce or plan (see Patočka, 1989/1953). If it was, morality would be always relative to our relative human ends. But where does the idea come from?

Throughout his work, Patočka confronts issues of morality, truth, politics and human living in the world, without the help of transcendence, in many different ways. 'Living in truth', the motto of Charta 77 popularised by Václav Havel (1989), is from Patočka's oeuvre. Again, we are looking at the difference between particular and general. Michael Kraus suggests that according to Havel and the other Charta 77 signatories, Václav Černý and Miroslav Kusý, Charta 77 aimed to bring into the open the pretension of the Czechoslovak government's "ideological façade of genuine socialism" and "to "restore the moral backbone, revive the respect for law, justice, and human dignity" (Kraus, 2007, p. 145). In contrast, for Patočka, "[t]he vision of living in truth" is a way of being able to give reasons for one's opinions while participating with others in a debate, where all accept being "corrected through a shared effort" (Patočka, 1989/1971, p. 223). For Patočka, morality, the commitment to justice and truth, is related to human action and responsibility. Responsibility is morality by another name; it means "a thousand-railed practice which nevertheless has a common sense, which we can...observe in acting" (Patočka, 2002b, p. 514, ellipsis in original). To be responsible means accepting that meaning is not secured, but that we have to search and fight for it. As he maintains, "[g]iven certain circumstances, [we] could make at least the human world a world 
of truth and justice" (Patočka, 2002a, p. 36, italics in original). The key word is 'human'. We can do no more.

To return to his claim from the text published alongside Charta 77, where he speaks of 'absolute morality', we need to realise that for Patočka, this is not the Kantian imperative (Patočka, 2015/1977). In the last essay he wrote, he explains that moral imperative, without the guarantee of God, is not binding - as Fyodor Dostoevsky showed in his portrayal of Ivan Karamazov (Dostoevsky, 2004). What we have to accept is Socratic 'learned ignorance'. Yet this does not mean that anything and everything goes: we must be able to give reasons for our claims and defend them in the company of others. As he writes in an unaddressed letter: "If there is a moral imperative, then it is to defend and generalize responsible life." For Patočka, there is not "any purpose in human life that would be beyond this human decision-making" (Patočka, 2002b, p. 514, italics in original). There is no transcendence to secure our human, finite meaning. We are finite human beings and we will never reach the absolute. We must accept our lot and realise that our lives must be lived by accepting that all meaning is never final; that tradition can help us but it will always be shaken; and that there is neither God nor Platonic Ideas nor Absolute Spirit that can give us an anchor that would keep the keel of our life straight and secure. This is, as he says, to accept positively the question of Jesus on the cross (Patočka, 2002c/1973, p. 413): "My God, my God, why hast thou forsaken me?" (Matthew 27:46) It is to realise that there is no God and never was, and that if there was, the answer would be: 'My son, I was never with you in the first place.' We are in this world alone, without the security of transcendence, but not without community.

\title{
Socrates
}

We always live in a shaken situation, but with others. For Patočka, a possible response is the "solidarity of the shaken". This is:

\begin{abstract}
"[T]he solidarity of those who understand. Understanding, though, must in the present circumstances involve not only the basic level, that of slavery and freedom with respect to life, but needs also to entail an understanding of the significance of science and technology, of that Force we are releasing. All the forces on whose basis alone can humans live in our time are potentially in the hands of those who understand. The solidarity of the shaken can say 'no' ... It will not offer positive programs but will speak, like Socrates' daimonion, in warnings and prohibitions. It can and must create a spiritual authority, become a spiritual power that could drive the warring world to some restraint, rendering some acts and measures impossible" (Patočka, 1996, p. 135).
\end{abstract}

The 'solidarity of the shaken' makes the experience of Socrates our own: it is to say 'no' to the abuse of the law and distortion of truth by the State's instrumental reasoning; to say 'no' to "the everydayness of the fact-crunchers and routine minds" (Patočka, 1996, p. 136); to say 'no' to abuse of the law and justice by refusing the instrumental explanation, while striving to give meaning to our lives. We need to accept that transcendence is no more, but we can search for new meaning through debate with others, by way of constant questioning of our cherished beliefs. It means taking responsibility for the world we live in.

This is what Patočka means by historicity in relation to Socrates. For Patočka, history begins with the realisation that meaning is not given and is certainly not secure forever. Every meaning can be questioned - as Socrates practised with others. We must ask naïve questions in order to search for new meaning; but we must also give reasons for our own opinions in order that they pass the litmus test that others impose on us. After all, we live in this world; and we should finally try to live from our own human resources, by refusing to invent another transcendence that would secure our human responsibility. We can neither prevent another Socrates from being sent to death, nor guarantee another Patočka (not) being crushed by the 
instrumentality of amoral government. But their deaths are also a sign, as Landgrebe said, that it is worth fighting for truth, justice and the law that applies to all of us, because we remember and keep fighting against this tyranny of instrumentality.

We must accept that without transcendence, meaning is never final, but this does not mean that there is no meaning. As Patočka said to his investigators: only through critique can we get things right. It is the duty of all of us to keep critiquing accepted meaning, otherwise we will end up at the mercy of either new tyrants or a society where 'everything goes' without any conviction on the part of its members. As he says, "no text whose content and purpose is the moral rehabilitation of society...can compromise this society" (as dictated to his interrogator on 12 Jan 1977, D 139, p. 452). He also acknowledges, as Socrates did a long time ago, that he took upon himself "this civic duty [because] he was convinced that if he did not do it himself, hardly anyone else would dare to do it". He did take up this call to fight for justice, although he was "aware of the fact that it will be a long-term affair and that he will hardly return to normal life" (as reported by the interrogator on 4 March 1977, D 57, p. 215). As Patočka wrote at another time, responsibility is "at the same time actuality, discipline (self-restraint), respect for others, and - wisdom". It is also "formation of one's self, the I, which was not there prior to the emergence of a responsible attitude" (Patočka, 2002b, p. 514, italics in original).

For Patočka, "[h]umans are in such a way that they simultaneously are and ought to be" (Patočka, 1998, p. 95, italics in original). According to him, we are historical humans, living in a situation that we were born into, but we are also "being[s] who [can] distinguish among that which is given, that which is lost and irretrievably gone, and that which does not yet exist except in the mode of unfulfilment in what is present" (Patočka, 1989/1953, p. 199). We have the ability to "struggle against the 'sheer reality', the reality that would impose itself on us as an absolute, inevitable, and invincible law" (Patočka, 1989/1953, p. 199). Knowing that life is ours only, there is no transcendence to give us guidance to our finite human ends. The world opens possibilities up for us, which we can take up; or we can refuse and pine for an outside guidance that can fill in our indecision with ends that are not ours. Or, we can realise that life is not easy and we have to fight for our own existence through a responsible attitude, recognising that we are responsible for the world where we live with others.

In a world without transcendence, there is no possibility of holding to something that is above and beyond our human life (as Kant's moral imperative would have it). There might not be a purpose in nature, nor in the world, but we can build a purpose into our own life. We can make binding human decisions from the meaning that has become shaken. History is this realisation that there is not, and cannot be, total meaning; but it is also a reminder that our search for meaning is never futile.

\section{Conclusion}

In this paper, I have argued that we should follow Patočka's understanding of Charta 77 as not only a document that confronts the misconduct of the Czechoslovak Socialist Republic in the 1970s, but also, and maybe primarily, as an attempt at general confrontation with the crisis of society. In Patočka's view, we need to confront the problem of techno-scientific reasoning stripped of its inner connection with the original spiritual foundation, which is also the problem of the transcendence that has become unthinkable in today's world. The problem of truth and morality is also a crisis in the domain of the meaning of human existence. The questioning of the role of the State and the incompatibility between the actions of government, law and morality is relevant to today's world, where instrumental rationality is dominant - since the problem is even more acute than it was in the 1970s. All governments today seem to have forgotten that 'planned' and human ends are incompatible. As Patočka proposes, human existence in the world is irreducible to instrumental rationality. Yet, how can 
we secure morality, truth and human meaning in a world without transcendence? His answer is Socrates and his learned ignorance: by questioning our inherited beliefs we can confront our shaken tradition and think anew what is important for humans. The solidarity of the shaken might help to bring the problems of truth, morality and human finite meaning to the fore, to help us to rethink them.

However, are those who can form the solidarity of the shaken really in possession of "[a]11 the forces on whose basis alone [humans can] live in our time" (Patočka, 1996, p. 135)? The excitement that Patočka felt with the uprising of students in the 1960s and the beginning of the 1970s seemed to point to a new spiritual beginning. He saw students as a new force coming into being, which could change the technical configuration of society. ${ }^{10}$ According to him, the intelligentsia, in the form of engineers, could change the configuration of society. That moment passed, even in Patočka's lifetime, as he acknowledged. ${ }^{11}$ In the world of today, mass communication separates us by accumulating our choices through clicks in the virtual world of the internet, while closing spaces where we could share our opinions with others. How, in this world of instant communication, can those who understand what is going on come together? This concern will have to be addressed in another paper.

\section{References}

ARENDT, H. (1998/1958): The Human Condition, $2^{\text {nd }}$ ed. Chicago \& London: The University of Chicago Press.

ARENDT, H. (2005): The Promise of Politics, ed. J. Kohn. New York: Schocken Books. BLAŽEK, P. (2017a): Úvod [Introduction]. In: P. Blažek (ed.): "Kéž je to všecko ku prospěchu obce!” Jan Patočka v dokumentech Státni bezpečnosti [“May it all be for the benefit of the community!" Jan Patočka in documents of Secret Police]. Prague: Academia \& Oikoymenh, pp. 9-23

BLAŽEK, P., ed. (2017b): “Kéž je to všecko ku prospěchu obce!” Jan Patočka v dokumentech Státní bezpečnosti ["May it all be for the benefit of the community!" Jan Patočka in documents of Secret Police]. Prague: Academia \& Oikoymenh.

BLUM, P. R. (2005): An interview with Stanislav Sousedík on the Czech Republic before and after Charta 77. In: Intellectual News, 15(1), pp. 7-12.

BOLTON, J. (2012): Worlds of Dissent: Charter 77, The Plastic People of the Universe, and Czech Culture under Communism. Cambridge, MA: Harvard University Press.

DOSTOEVSKY, F. (2004): The Grand Inquisitor. In: F. Dostoevsky: The Brothers Karamazov: A Novel in Four Parts with Epilogue. London: Vintage Books, pp. 246-264.

HAVEL, V. (1989): Living in Truth, trans. P. Wilson and others, ed. J. Vladislav. London \& Boston: Faber and Faber.

HUSSERL, E. (1970): The Crisis of European Sciences and Transcendental Phenomenology: An Introduction to Phenomenological Philosophy, trans. D. Carr. Evanston: Northwest University Press.

JARVINEN, J. (2009): Normalization and Charter 77: Violence, Commitment and Resistance in Czechoslovakia. Helsinki: University of Helsinki.

KRAUS, M. (2007): Did the Charter 77 Movement Bring an End to Communism? In: New England Review, 28(2), pp. 134-146.

LANDGREBE, L. (1977): Jan Patočka. In: Philosophy and Phenomenological Research, 38(2), pp. 287-290.

\footnotetext{
${ }^{10}$ Interestingly, a similar sentiment had already been expressed by Thorstein Veblen in his book The Engineers and the Price System, from 1921, with a very different hope, needless to say (Veblen, 2001/1921).

${ }^{11}$ For a discussion on Patočka's hope concerning the intelligentsia, see "Translators' Preface" (Patočka, 2016a; Patočka, 2016b).
} 
MATUŠTÍK, M. (2007): 'More than All the Others': Meditation on Responsibility. In: Critical Horizons, 8(1), pp. 47-60.

MOORE, C. (2010): Jan Patočka and Global Politics. In: C Moore \& C. Farrands (eds.): International Relations Theory and Philosophy: Interpretive Dialogues. London: Routledge, pp. 80-146

NIETZSCHE, F. W. (1974/1882): The Gay Science: With a Prelude in Rhymes and an Appendix of Songs, trans. W. Kaufmann. New York: Vintage Books.

PATOČKA, J. (1989/1953): Negative Platonism: Reflections Concerning the Rise, the Scope, and the Demise of Metaphysics - and Whether Philosophy Can Survive It. In: E. Kohák (ed.): Jan Patočka. Philosophy and Selected Writings. Chicago \& London: The University of Chicago Press, pp. 175-206.

PATOČKA, J. (1989/1971): Edmund Husserl's Philosophy of the Crisis of the Sciences and his Conception of a Phenomenology of the 'Life-World'. In: E. Kohák (Ed.): Jan Patočka: Philosophy and Selected Writings. Chicago and London: The University of Chicago Press, pp. 223-238.

PATOČKA, J. (1989/1977): The Obligation to Resist Injustice. In: E. Kohák (ed.): Jan Patočka. Philosophy and Selected Writings. Chicago \& London: The University of Chicago Press, pp. 340-343.

PATOČKA, J. (1996): Heretical Essays in the Philosophy of History, trans. E. Kohák, ed. J. Dodd. Chicago \& La Salle, IL: Open Court.

PATOČKA, J. (1998): Body, Community, Language, World, ed. J. Dodd. Chicago \& La Salle, IL: Open Court.

PATOČKA, J. (2002a): Plato and Europe, trans. P. Lom. Stanford, CA: Stanford University Press.

PATOČKA, J. (2002b): Zodpovědnost [Responsibility. Fragment of a letter]. In: I. Chvatík \& P. Kouba (eds.): Sebrané spisy Jana Patočky, sv. 3 [Collected Works of Jan Patočka, vol. 3]. Prague: Oikoymenh, p. 514.

PATOČKA, J. (2002c/1973): Čtyři semináře k problému Evropy [Four seminars towards Europe's problem]. In: I. Chvatík \& P. Kouba (eds.): Sebrané spisy Jana Patočky, sv. 3 [Collected Works of Jan Patočka, vol. 3]. Prague: Oikoymenh, pp. 374-423.

PATOČKA, J. (2006/1976): K záležitostem Plastic People of the Universe a DG 307 [On the Matters of The Plastic People of the Universe and DG 307]. In: K. Palek \& I. Chvatík (eds.): Sebrané spisy Jana Patočky, sv. 12 [Collected Works of Jan Patočka, vol. 12]. Prague: Oikoymenh, pp. 425-427.

PATOČKA, J. (2007/1948): Věčnost a dějinnost [Eternity and historicity]. In J. Patočka: Věčnost a dějinnost: Rádli̊v poměr $k$ pojetím člověka $v$ minulosti a současnosti [Eternity and History: Rádl's Ratio to the Concepts of Man in the Past and Present]. Prague: Oikoymenh, pp. 19-123.

PATOČKA, J. (2015/1977): On Masaryk's Philosophy of Religion. In: L. Hagedorn \& J. Dodd (eds.): The New Yearbook for Phenomenology and Phenomenological Philosophy, vol. 14. Religion, War and the Crisis of Modernity. A Special Issue Dedicated to the Philosophy of Jan Patočka, pp. 95-135.

PATOČKA, J. (2016a): Intellectuals and Opposition. In: F. Tava \& D. Meacham (eds.): Thinking After Europe: Jan Patočka and Politics. London: Rowman \& Littlefield International, pp. 7-21.

PATOČKA, J. (2016b): Intellectuals and Opposition: Alternative End. In: F. Tava \& D. Meacham (eds.): Thinking After Europe: Jan Patočka and Politics. London: Rowman \& Littlefield International, pp. 23-26.

PATOČKA, J. (2017): On the Matters of The Plastic People of the Universe and DG 307, trans. J. Majernik. Draft, pp. 1-3. 
PLACÁK, P. (2017a): Kacířské eseje čili Samizdat z ministerstva financí: Rozhovor Babylonu s Ivanem Chvatíkem nejen o Patočkovi [Heretical Essay or Samizdat from the Treasury: Interview by Babylon with Ivan Chvatík not only about Patočka]. In: Babylon: Studentský list pro seniory (Literární a výtvarná př́loha), 26(2), pp. iv-vi.

PLACÁK, P. (2017b): Život, smrt a pohřeb filosofa: Rozhovor Babylonu s historikem Petrem Blažkem o Janu Patočkovi [Life, Death, and Funeral of the Philosopher: Interview of Babylon with historian Petr Blažek about Jan Patočka]. In: Babylon: Studentský list pro seniory (Literární a výtvarná př́loha), 26(2), pp. i-ii, vi.

PLATO (1997): Euthyphro. In: J. M. Cooper (ed.): Complete Works. Indianapolis \& Cambridge: Hackett Publishing, pp. 2-16.

RANCIËRE, J. (1999): Dis-agreement: Politics and Philosophy, trans. J. Rose. Minneapolis \& London: The University of Minnesota Press.

RICCEUR, P. (1996): Preface to the French Edition of Jan Patocka's Heretical Essays. In: J. Patočka: Heretical Essays in the Philosophy of History. Chicago \& La Salle, IL: Open Court, pp. vii-xvi.

SKILLING, H. G. (1981): Charter 77 and Human Rights in Czechoslovakia. London: Harper Collins Publishers.

TAMINIAUX, J. (1997): The Thracian Maid and the Professional Thinker. Arendt and Heidegger, trans. M. Gendre. Albany: State University of New York Press.

UNITED NATIONS. (2017): International Covenant on Civil and Political Rights. United Nations Human Rights Office of the High Commissioner 2017, [online] [Retrieved 16 December 2017]. Available at: http://www.ohchr.org/EN/ProfessionalInterest/Pages/CCPR.as px.

VEBLEN, T. (2001/1921): The Engineers and the Price System. Kitchener: Batoche Books. 